\title{
SMART SPECIALISATION DEVELOPMENT IN LATVIA
}

\author{
Sergejs Gemma, Zane Vïtolina \\ Latvia University of Life Sciences and Technologies, Latvia \\ ef15161@1lu.lv
}

\begin{abstract}
Based on data on the number of newly established enterprises and the total number of enterprises, the authors analysed whether and what changes occurred in the industries of the national economy that have high transfer potential in relation to smart specialisation implementation in the country, broken down by region, thereby identifying the RIS 3 specialisation field on which the focus has to be placed and to which attention has to be drawn.

The aim of the research is to identify the entrepreneurship development in RIS3 specialisation fields broken down by region and economic development according to the RIS3 specialisation fields.

The research has found that the number of enterprises in the industries having high transfer potential in relation to RIS3 as a percentage of the total number of enterprises was slightly above $50 \%$; the regional breakdown of the enterprises revealed that two thirds were located in the regions of Riga and Pieriga, and that ICT was the most significant RIS3 specialisation.

In the post-crisis period, the number of newly established enterprises increased at the highest rate in 2011, exceeding the rate of the previous year more than two-fold, whereas in the next two years the rate decreased below the 2009 level.
\end{abstract}

Key words: smart specialisation strategy, regional development, NACE code.

\section{Introduction}

The national strategy for smart specialisation has an ex ante conditionality for the European Union (EU) Structural Funds use from 2014 to 2020 . The strategy envisages detecting smart specialisation priorities with the greatest potential to increase the competitiveness of national economies and mobilising resources for implementing the priorities (Boekholt et al., 2015).

Smart specialisation strategy (RIS3) represents an explicit and place-based approach, while emphasizing prioritization and selectivity through non-neutral, vertical policies, and thereby acknowledging the large variations in regional policy challenges as regards promoting innovation, competitiveness and growth (Grillitsch \& Asheim, 2018). Therefore, each region or country sets the fields and priorities for RIS3 that are most relevant to their development.

The Smart Specialisation Strategy of Latvia (RIS3) sets five RIS3 specialisation fields: (1) knowledgebased bio-economy, (2) biomedicine, medical technologies, biopharmacy and biotechnologies, (3) advanced materials, technologies and engineering systems, (4) smart energy and (5) information and communication technologies (ICT) (Gemma, Vìtolina, 2017). The authors analysed changes in the number of enterprises operating in the industries of the national economy with high transfer potential, particularly for RIS3 specialisation fields, over a five-year period. Latvia has defined the RIS3 specialisation fields as the driver for new economic policies in relation to smart specialisation.

The authors acquired data for the period 2009 2014, then the data were processed and examined, splitting them into two data groups. The first data group represented a control period from 2009 to 2013. The research analysed the proportion of newly established enterprises in the RIS3 specialisation fields defined (the research examined and analysed the choice of RIS3 specialisation fields by comparing expert opinions and real trends in the industries). The second data group represented the year 2014 as a control period. The research examined the total number of enterprises in the RIS3 specialisation fields in Latvia by NACE code - the kinds of economic activity.

As this is the first step of the research, the current task is to clarify the boundary line when the RIS3 was adopted. Further analysis will be continued for the recent years.

The aim of the research is to identify entrepreneurship development in RIS3 specialisation fields broken down by region and economic development according to the RIS3 specialisation fields. To achieve the aim, the following specific research tasks were set: 1) to identify the number of newly established enterprises in $2009-2013$ in industries with high transfer potential according to the RIS3 specialisation fields by region in Latvia; 2) to assess changes in the number of newly established enterprises in the regions; 3 ) to identify the number of enterprises by region in the RIS3 specialisation fields based on the data on the number of enterprises for 2014.

The research methods used were: monographic, comparison, abstract analysis and logical construction, synthesis and analysis, induction and deduction, the graphical method and statistical analysis.

\section{Materials and Methods}

To discuss the RIS3 specialisation fields proposed by the experts, 14 public discussions, in which more 
Table 1

\section{Consistency of the RIS3 specialisations with industries having high transfer potential}

\begin{tabular}{|c|c|c|c|c|c|}
\hline Industry & $\begin{array}{l}\text { Knowledge- } \\
\text { based bio- } \\
\text { economy }\end{array}$ & $\begin{array}{l}\text { Biomedicine, } \\
\text { medical } \\
\text { technologies, } \\
\text { biopharmacy and } \\
\text { biotechnology }\end{array}$ & $\begin{array}{l}\text { Advanced materials, } \\
\text { technologies and } \\
\text { engineering systems }\end{array}$ & Smart energy & ICT \\
\hline Agriculture, forestry & $01 ; 02 ; 03$ & $01 ; 02 ; 03$ & & & \\
\hline Other manufacturing & $\begin{array}{l}05 ; 06 ; 07 ; 08 ; \\
09 ; 35 ; 36 ; 37 ; \\
38 ; 39\end{array}$ & & & $\begin{array}{l}05 ; 06 ; 07 ; 08 ; \\
09 ; 35 ; 36 ; 37 ; \\
38 ; 39\end{array}$ & \\
\hline Food industry & $10 ; 11$ & $10 ; 11$ & & & \\
\hline Light industry & $13 ; 14 ; 15$ & & & & \\
\hline Wood processing & $16 ; 31$ & & $16 ; 31$ & & \\
\hline $\begin{array}{l}\text { Manufacture of non- } \\
\text { metal minerals }\end{array}$ & 23 & & 23 & 23 & \\
\hline Metalworking & & & $24 ; 25$ & $24 ; 25$ & \\
\hline $\begin{array}{l}\text { Manufacture of } \\
\text { electrical and optical } \\
\text { equipment }\end{array}$ & $26 ; 27$ & $26 ; 27$ & $26 ; 27$ & & $26 ; 27$ \\
\hline $\begin{array}{l}\text { Manufacture of } \\
\text { machinery and } \\
\text { equipment }\end{array}$ & 28 & & 28 & 28 & \\
\hline $\begin{array}{l}\text { Manufacture of } \\
\text { vehicles }\end{array}$ & $29 ; 30$ & & $29 ; 30$ & $29 ; 30$ & \\
\hline $\begin{array}{l}\text { Other commercial } \\
\text { services }\end{array}$ & & & & & $58-82 ; 90-96$ \\
\hline Public services & & $84-88$ & & & $84-88$ \\
\hline
\end{tabular}

Source: authors' calculations based on Viedās specializācijas stratēgijas..., 2017.

than 500 representatives from scientific institutions, education institutions and producer associations took part, were held in 2014. The discussions concluded that the industries of the national economy of Latvia were relatively highly specialised; for this reason, overall, it was not a problem of the national economy of Latvia (Informatīvais ziņojums..., 2017).

The research period was the period of $2009-2019$ to see whether the opinions of the discussions and experts were in line with the defined specialisation fields for the period concerned. The data were acquired from the Lursoft database. The data on newly established enterprises pertain to the enterprises that have been registered, have operated for 12 - 18 months and have submitted an annual report on their performance. The data selected allowed to identify the main change in the growth of industries in municipalities and cities.

The research selected data only on the industries with high transfer potential that were broken down by RIS3 specialisation field (Table 1). In order to analyse the data by region, the data were selected for six statistical regions. The statistical regions are enshrined in national legal acts and agreed with the EU statistical bureau Eurostat. Six statistical regions are established in Latvia: Riga, Pieriga, Vidzeme, Kurzeme, Zemgale and Latgale (Par statistiskajiem regioniem, 2018). Across the regions of Latvia there can be still observed considerable socioeceonomic disparities with the monocentric capital city-oriented development, distribution of people and economic activities (Jermolajeva et al., 2017).

The kinds of economic activity registered by enterprises are specified by NACE codes. NACE is an abbreviation in French "Nomenclature statistique des activités économiques dans la Communauté européenne" or the standard classification of productive economic activities in the European Union. Every NACE code corresponds to some kind of business an enterprise is engaged in (What is a..., n.y.).

Actually any industry can potentially use some RIS3 specialisation field; for this reason, the authors focused only on the industries that have high transfer potential. Table 1 shows the RIS 3 specialisation fields 
that could relate to the industries with high transfer potential (coloured), as well as corresponding NACE codes, i.e. indicating which kinds of economic activity were selected.

\section{Results and Discussion}

First of all, insight into the situation in the regions - a breakdown of enterprises by statistical region - was obtained, analysing the number of operating enterprises in the industries with high transfer potential by statistical region (Figure 1). The analysis clearly reveals that the monocentric pattern of development is explicitly characteristic of Latvia, as two thirds of enterprises have registered their economic activity in the capital city or in the vicinity of it (statistical regions of Riga and Pieriga). Monocentric development in particular is referred to as one of the problems of the innovation system of Latvia; it creates an unfavourable environment for entrepreneurship in the regions and contributes to depopulation and inefficient use of resources of a region. As the researchers Kreslins and Stefenberga admit, trends in regional development still are fairly monocentric, and according to RIS3 strategy there should be the development of economics and entrepreneurship in all regions, and best practices should be introduced outside the borders of a region (Kreslins \& Stefenberga, 2016). With monocentric development continuing in Latvia, the competitiveness of the country is going to decrease, as the cost of labour and infrastructure in the monocentre is going to rise, while opportunities for growth in the regions will not be used (Informatīvais ziņojums..., 2013).

Among the other four regions, the highest performance was reported in Kurzeme region where
$9 \%$ of the total operating enterprises engaged in the industries with high transfer potential in relation to RIS3 were registered. Two seaports of national significance are located in this region. The poor performance of Zemgale and Vidzeme might be explained by the fact that the regions have only one city of national significance (Jelgava in Zemgale and Valmiera in Vidzeme). The number of registered enterprises in Latgale is higher by one percentage point, as this region has two cities of national significance - Rezekne and Daugavpils, the latter of which is the second largest city in Latvia.

The analysis of the number of enterprises in the industries with high transfer potential broken down by RIS3 specialisation field (Figure 2) reveals that more than half of them were engaged in ICT, which encompasses such industries as manufacture of electrical and optical equipment, information and communication services, financial and insurance activities, real estate activities, professional, scientific and technical services, education, health, art, entertainment and recreation. The calculations were done taking into account the enterprises that had operated for more than a year as of 2014 and had submitted annual reports, in which they declared their kind of economic activity. This RIS3 specialisation field encompasses a lot of industries with high transfer potential (37 NACE codes); consequently, the number of enterprises in this field is large. The next largest RIS3 specialisation field, in terms of number of enterprises with high transfer potential, is the knowledge intensive bioeconomy, while smart energy accounts for only $4 \%$ of the total enterprises.

As shown in Figure 2, nationally more focus should be placed on the fields of smart energy and

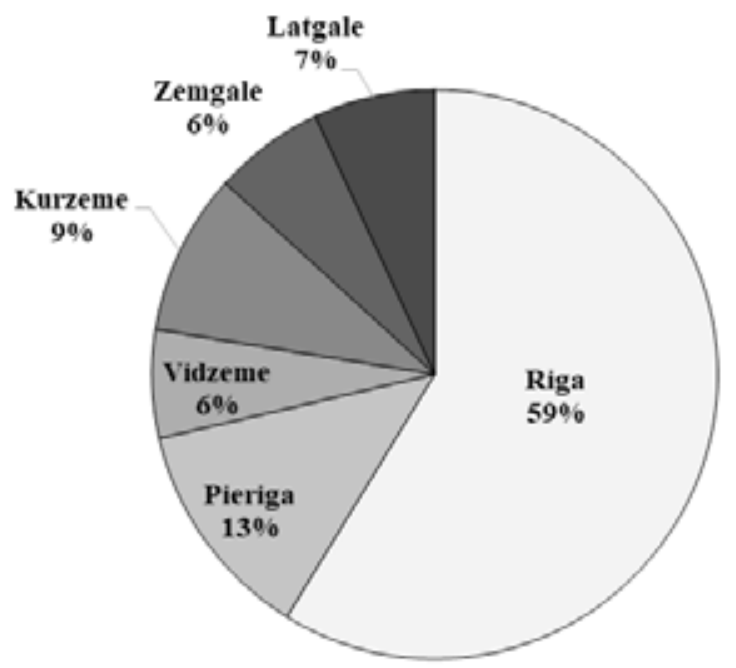

Source: authors' calculations based on Lursoft data.

Figure 1. Percentage breakdown of enterprises of industries with high transfer potential by statistical region in 2014 . 


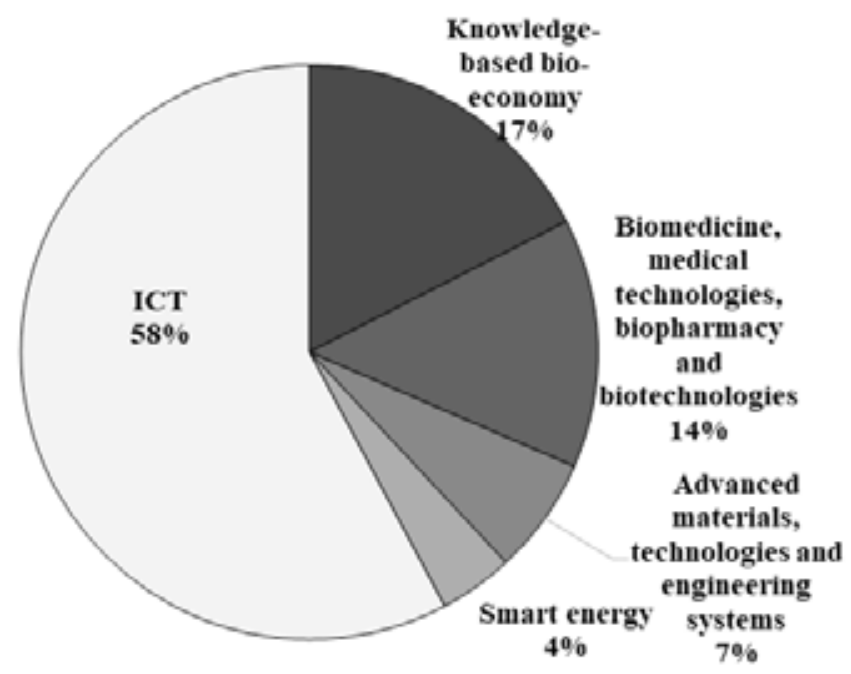

Source: authors' calculations based on Lursoft data.

Figure 2. Percentage breakdown of enterprises registered in 2014 by sector with high transfer potential in relation to RIS3.

advanced materials, technologies and engineering systems in order to increase their proportions.

The number of newly established enterprises also indicates the economic development in the country. An analysis of the number of newly established enterprises in the period $2009-2013$ reveals interesting dynamics. The data on the number of newly established enterprises operating in the industries having high transfer potential in at least one RIS3 specialisation field were selected for the analysis. The economic situation of this period could be characterised as a post-crisis time, although the number of newly established enterprises in the industries with high transfer potential pertaining to RIS3 was slightly larger compared with 2010. A considerable increase in the number of newly established enterprises occurred in 2011, which indicated a decline in the economic crisis. The largest number of enterprises in Riga in 2011 was reported in the field "real estate activities" (NACE code 68) - 469 newly established enterprises were registered in that year. In 2012, the number of newly established enterprises decreased by half, while in 2013 their number continued decreasing and was even below the 2009 level, thereby stabilising the situation in the real estate market that stagnated during the crisis.

The numbers of newly established enterprises registered in Riga and Pieriga were significantly larger, while in the other four regions the numbers of such enterprises were approximately the same in every year analysed. The above data were compared with the total number of newly established enterprises

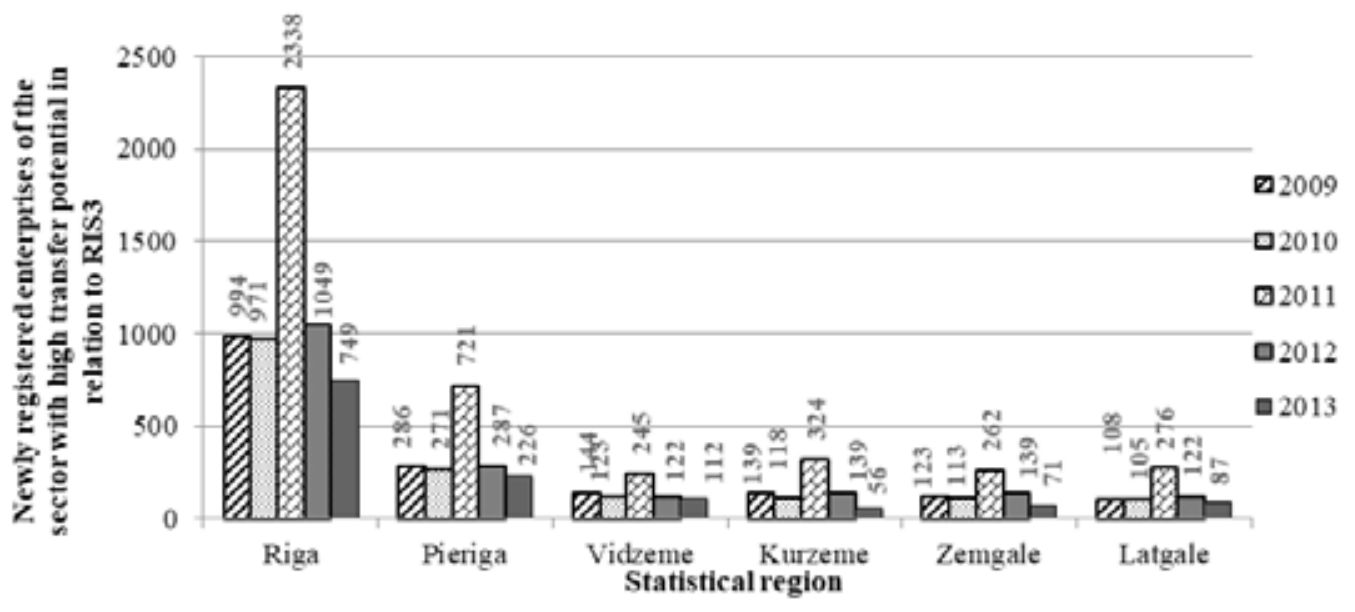

Source: authors' calculations based on Lursoft data.

Figure 3. Number of newly registered enterprises of the sector with high transfer potential in relation to RIS3 in the statistical regions in the period $2009-2013$. 


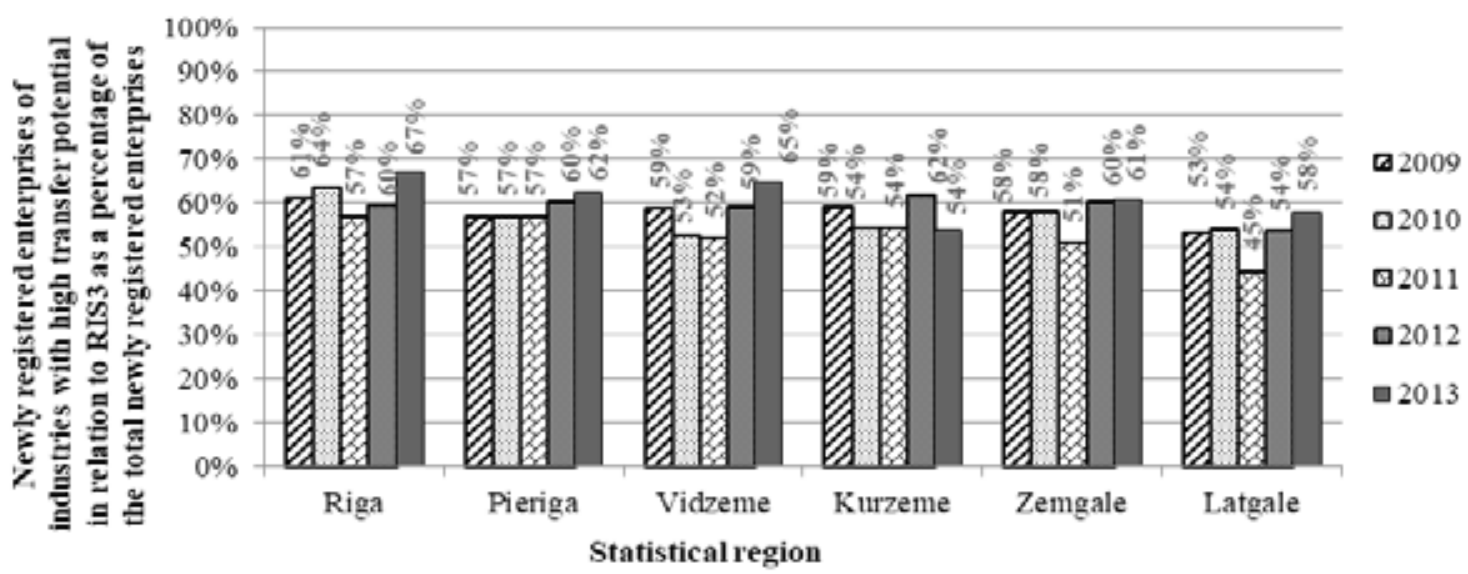

Source: authors' calculations based on Lursoft data.

Figure 4. Number of newly registered enterprises of industries with high transfer potential in relation to RIS3 as a percentage of the total newly registered enterprises in the statistical regions in the period $2009-2013$.

in the entire economy (Figure 4), which revealed that the number of newly established enterprises in the industries with high transfer potential in relation to RIS3 expressed as a percentage of the total was, on average, slightly above $50 \%$. It is worth mentioning that the significant increase in the number of enterprises in 2011 was reported particularly in the industries having no potential relation to RIS3, as the proportion of RIS3 fields in this year was even lower than in the other years analysed. In 2013 in all the regions, except Kurzeme, the proportion of RIS3 fields was the highest, which indicated progress in smart specialisation in the economy of Latvia.

Researcher Rivza with colleagues, using the same Lursoft data in the same period about Zemgale region entrepreneurship, discovered that the pace of economic growth differs among the municipalities. Comparing two indicators - increase in the total number of enterprises and the number of knowledgebased enterprises for the period $2009-2013$ in five municipalities of Zemgale region, the total number of enterprises from 2009 to 2013 rose faster than that of knowledge-based enterprises, and the proportion of knowledge-based enterprises decreased from 8.2 to $6.4 \%$. In other 15 municipalities an increase in the number of knowledge-based enterprises from 2009 to 2013 considerably exceeded an increase in the total number of enterprises, and their proportion rose from 12.1 to $15.0 \%$. Increase differs significantly in each municipality, even in two municipalities of the Zemgale region the proportion of this kind of enterprises was greater than $20 \%$ of the total enterprises. It shows that the smart economic growth is also determined by municipal government performance, the activity of various public institutions and residents' readiness to work under the guidance of the institutions and organizations (Rivza et al., 2016).
The regional distribution of the industries with high transfer potential in relation to RIS3 in all the regions was similar, only in Latgale the proportion was slightly lower. In general, Latgale region is recognized as economically least developed region in Latvia (Jermolejeva et al., 2017).

The Figure 4 shows that in 2013, comparing with the data of 2009, the number of newly registered enterprises of industries with high transfer potential in relation to RIS3 as a percentage of the total newly registered enterprises decrease in all statistical regions of Latvia. This negative dynamics is also directly related to the RIS3 macroeconomic indicator "the proportion of innovative enterprises", where the share of innovative enterprises has sharply dropped, even below the base value of 2012. And it is quite clear that the target value of 2020 cannot be achieved (Šmīdlere, 2017).

Speaking about further development in Riga and Pieriga regions, the basis for regional economic development forms the attraction of new technologies, the promotion of innovation and improvement of the regional resource base. The development of these factors can be achieved with the structural reform planning (Rivza et al., 2017).

\section{Conclusions}

1. A monocentric trend in the regional distribution of the industries with high transfer potential in relation to RIS3 was observed, as almost two thirds of enterprises have registered their economic activity in Riga and its vicinity. Among the other regions, the best performer was Kurzeme region where $9 \%$ of the total enterprises in the industries with high transfer potential in relation to RIS3 were registered.

2. Among the RIS3 specialisation fields, ICT accounted for the highest proportion - more than 
half - which also encompassed the largest number of industries, while smart energy made up only $4 \%$, which requires seeking solutions to foster the development of this field.

3. In the post-crisis period, the number of newly established enterprises in 2011 was two times larger than in 2010, while in 2009, 2010, 2012 and 2013 the numbers were almost equal. One can conclude that no considerable economic growth was observed in the analysis period.

4. The number of newly established enterprises in the industries having high transfer potential in relation to RIS3, expressed as a percentage of the total newly established enterprises in the entire economy, reveals that in the period 20092013 in all the regions, except Kurzeme, the highest percentage of industries related to RIS3 was observed particularly in the last year, which indicated progress in smart specialisation in the economy of Latvia.

\section{Acknowledgement}

The research was supported by the project "Strengthening Research Capacity in Latvia University of Agriculture" (agreement No 3.2.-10/43).

\section{References}

1. Boekholt, P., Clar, G., Nauwelaers, C., Saublens, C., \& Tiits, M. (2015). Perspectives for Research and Innovation Strategies for Smart Specialisation (RIS3) in the wider context of the Europe 2020 Growth Strategy. European Commission. Retrieved January 5, 2018, from: http://ec.europa.eu/research/regions/ pdf/publications/ris3_report-082015.pdf.

2. Gemma, S., \& Vītoliņa, Z. (2017). Smart specialization strategy in Latvia, Estonia and Lithuania. Economic Science for Rural Development. Volume 45, pp. 71-78.

3. Grillitsch, M., \& Asheim, B. (2018). Place-based innovation policy for industrial diversification in regions. European Planning Studies. Volume 26, Issue 8, pp. 1638-1662, DOI: 10.1080/09654313.2018.1484892.

4. Informatīvais ziņojums "Par viedas specializācijas stratēgijas izstrādi" (Development of a Smart Specialization Strategy for Latvia: informative report). (2013). Retrieved January 13, 2018, from: http:// tap.mk.gov.lv/mk/tap/?pid=40291636. (in Latvian).

5. Informatīvais ziņojums "Viedās specializācijas stratēǵijas monitorings" (Smart specialization strategy monitoring: informative report). (2017). Retrieved November 12, 2017, from: http://tap.mk.gov.lv/lv/mk/ tap/?pid=40427624. (in Latvian).

6. Jermolajeva, E., Rivza, B., Aleksejeva, L., Sipilova, V., \& Ostrovska, I. (2017). Smart growth as a tool for regional convergence: evidence from Latgale region of Latvia. Economics and Sociology. Volume 10, Issue 4, pp. 203-224.

7. Kreslins, K., \& Stefenberga, D. (2016). Analysis of Kurzeme Region Development in the Context of Smart Specialization Strategy: Preliminary results. Engineering for Rural Development. Volume 15, pp. 1224-1229.

8. Par statistiskajiem regioniem (Aubout the statistic regions) (2018). Central Bureau of Statistics. Retrieved January 25, 2018, from: http://www.csb.gov.lv/dokumenti/par-statistiskajiem-regioniem-28607.html. (in Latvian).

9. Rivza, B., Azena, L., \& Rivza, P. (2017). Evaluation of smart economy development in the Riga planning region (LATVIA). Agronomy Research. Volume 15, Issue 5, pp. 2068-2078.

10. Rivza, B., Kruzmetra, B., \& Zaluksne, V. (2016). Performance trends for smart growth in the rural territories of Latvia. Agronomy Research. Volume 14, Issue 5, pp. 1684-1693.

11. Šmīdlere, S. (2017). RIS3 monitoringa ieviešanas progress (Progress in the implementation of RIS3 monitoring). Report of the EU finds 2014-2020 annual planning period Supervisory Committee. Retrieved January 15, 2018, from: https://komitejas.esfondi.lv/...9_IZM_RIS3_UK_precizets_10052017.pptx. (in Latvian).

12. What is a NACE code? Retrieved January 25, 2018, from: https://siccode.com/en/pages/what-is-a-nacecode. 